\title{
University of New South Wales
}

\author{
Kirk Dodd
} Re-inventing Shakespeare: his methods of inventio and a new 'Shakespearean'
play called Bennelong

\begin{abstract}
:
Most Renaissance grammar schoolboys would have been trained in a tripartite process of rhetorical composition - inventio, dispositio and elocution - yet there has been an incorrect tendency to analyse only Shakespeare's application of rhetorical figures as Shakespeare's application of rhetoric. Rhetorical figures concern only the third and final method of composition, elocutio, and whilst methods of inventio (discovering arguments) and dispositio (arranging those arguments) seem more ideational than they do textual, we should not exclude the prospect of finding evidence for Shakespeare's applications of inventio methods in his work. This paper will introduce the still-emerging field of Shakespeare's inventio and the strategies I have developed to find evidence for this part of Shakespeare's creative process - evidence that I suggest is hiding in plain view, camouflaged, as it were, before our every eyes. I will argue that Shakespeare's use of inventio methods conforms to Cicero's treatise on rhetorical invention, and present three analyses of Shakespeare's application of the topics: notatio, contraries, and definitions. I will then illustrate the practical applications of inventio methods by demonstrating how I have re-applied these findings to my own blank verse drama called Bennelong, which aims to achieve a 'Shakespearean' aesthetic.
\end{abstract}

\section{Biographical note:}

Kirk Dodd is finalizing his PhD in Creative Writing at the University of New South Wales (UNSW). His thesis examines Shakespeare's creative application of Cicero's topics of invention and develops an Australian blank verse drama (Bennelong) that aims to achieve a 'Shakespearean' aesthetic. Kirk has lectured on Shakespeare at UNSW and taught classes on Early Modern to Modern English texts. His research interests include Shakespeare and Renaissance studies, classical rhetoric, poetics, the ethos of imitatio specialis, the novel, Henry James, and historiographic metafiction.

Keywords:

Creative writing - William Shakespeare - Rhetoric - Invention 


\section{Introduction}

Sixteenth-century English pedagogy was largely based on Humanist training in rhetorical composition (Enterline 2012: 1), drawing on the classical precepts of the ancient Greeks and Romans of whom Cicero was the Latin authority during the English Renaissance (Donker and Muldrow 1982: 33). Even by Cicero's time, the tripartite approach to composition using the three modes of inventio, dispositio, and elocutio was firmly established, yet as Hunter and Skinner have noted (1994: 104, 2014: 4), there has been an incorrect tendency in recent scholarship to refer only to Shakespeare's use of rhetorical figures as his application of rhetoric. Applying rhetorical figures belongs to the third and final phase of composition (elocutio), whilst Shakespeare and other Elizabethans would have been trained in the arts of inventio (the discovery of arguments) and dispositio (the arrangement of those arguments for persuasive effect). In this paper, I will introduce Shakespeare's applications of rhetorical inventio as a subfield of Shakespeare studies yet to be properly established. I will argue throughout that Shakespeare was conversant with Cicero's mature treatise on topical invention and applied these methods in his work, presenting three case studies of Shakespeare's apparent application of Cicero's topics: notatio, contraries, and definitions. The latter part of this paper will discuss how these practical precepts can then be re-applied to new verse dramas that aim to achieve a 'Shakespearean' aesthetic. My own play, The Tragicall Hiftorie of Woollarawarre Bennelong, Native Ambassador of Nova Hollandia, seeks to harness something of Shakespeare's epic sweep and rhetorical force by imitating his methods of composition, and I will demonstrate how a number of excerpts from this play have been influenced by my findings regarding Shakespeare's inventio. These findings can therefore contribute to both Shakespeare and creative writing pedagogies. To begin, however, let us first examine the components of Cicero's topical treatise on invention.

\section{What is inventio?}

Methods of inventio ask us to consider a subject according to certain prescribed 'topics' or loci to help invent arguments to construct an oration. Many of these topics were specific to particular types of discourse (such as a legal defence, or jurisdictional matter), until Cicero became the first to devise a topical treatise that was comprehensive and universal for any subject whatsoever - thus applicable to all three branches of oratory: legal, political, or ceremonial. Cicero states implicitly that once 'you have journeyed through' all sixteen of his artificial topics 'no region of arguments remains to be explored' (Topica XIX.72 [437]). He does not quite state that you will know everything there is to know about a subject implicitly, but he comes close by suggesting that you will know everything you need to know in order to construct a persuasive oration. This implies that those familiar with his topics would never suffer from writer's-block and could readily become experts on any subject they wished to discuss. Cicero outlines his treatise of sixteen artificial topics and one inartificial topic most comprehensively in his Topica (c.44 BC), claiming that his sixteen artificial topics were inherent to the subject because they could be determined artificially by the author. These are: 
[1] Definition

[2] Enumeration (of whole \& parts) or Division (of genus \& species)

[3] Notatio: name or etymology

[4] Conjugates

[5] Genus (if conceptual) or Whole (if material)

[6] Species (if conceptual) or Parts (if material)

[7] Similarities

[8] Differences

[9] Contraries

[10] Adjuncts

[11] Consequents

[12] Antecedents

[13] Repugnants - things incompatible (with consequents or antecedents)

[14] Cause

[15] Effect

[16] Comparisons - to things greater, less or equal (Topica, II.9-IV.23: 389-397; V.27XVIII.71: 399-437)

The Latin connotation for inventio stems from invenire, meaning to come upon or discover something already in existence (OED I.1.a, d). Thus topics were also called loci, or 'places', where arguments could be located. The singular external topic for Cicero is 'authority' or 'testimony', which concerns bringing in evidence extrinsic to the subject to support one's case such as witness testimony, contracts, precedents, and the like - these are inartificial because they are not determined by the techniques of composition. For purposes of clarity, my examination is concerned only with Cicero's sixteen artificial topics listed above.

Cicero refers briefly to the same comprehensive treatise in his most famous rhetorical work, De oratore (c.55 BCE) (II.XXXIX.162-II.XL.172 [315-321]), as well as the manual written for his son, De partitione oratoria (c.46 BCE) (II.7 [315-17]), and these texts followed some 30-40 years' experience as a lawyer, politician, and philosopher. The treatise of Cicero's Topica (c.44 BC) is therefore known as Cicero's 'mature treatise' because he refers to the same topical system throughout the final decade of his career - compared to his less systematic discussions of mainly forensic topics in $D e$ inventione (c. $87 \mathrm{BC}$ ), written when Cicero was a teenage graduate about to begin his extensive career. Whilst many will claim that methods of topical invention are modes of dialectic (or logic), I refer to Cicero's treatise as a rhetorical mode because that is how Cicero frames his approach to invention.

During the Renaissance, Rudolph Agricola developed a treatise of twenty-four topics of invention (largely modelled on Cicero's) in De inventione dialectica (c.1479), and Philip Melanchthon's, Erotemata dialectices (1547), offers eleven topics for persons and twenty-eight topics for things, whilst Thomas Wilson's Rule of Reason (1553) offers twenty-four topics that are essentially the same as Agricola's (Altman 2010: 124). Agricola's greater number of topics results by his exclusion of Cicero's antecedents, consequents, and repugnants - which he believed to be forms of argument rather than loci where arguments could be found (Mack 1993: 148), as well as the topic of enumeration/division. This leaves Agricola with twelve Ciceronian topics, to which 
he adds 'opinion' (equated with Cicero's extrinsic topic 'testimony'), wholes and parts (which Cicero discusses under genus and species), then replaces Cicero's 'adjuncts' with seven intricate subdivisions: adjacents, action, subject, time, place, connexa and contingents. This adds ten topics to the twelve whilst dropping 'adjuncts' to reach twenty-one, to which Agricola adds the topics of 'property', 'final cause', and 'destinata', to arrive at twenty-four topics. Mack provides a chart that compares Cicero's and Agricola's treatises in Renaissance Argument (147).

\section{Why should Shakespeare prefer Cicero's treatise?}

A near-complete version of Cicero's mature treatise appears in Erasmus's De copia (1978: 606) - though he gives little credit to Cicero - as well as in Erasmus's De conscribendis epistolis (1985: 122-29). Where Erasmus had a great influence on Humanist pedagogy particularly in England, it is these two texts that were the bestsellers for Erasmus during the Renaissance (Mack, 2013: 31, 87, 91). This suggests a great likelihood that the texts were included in the curricula for many English grammar schools (Mack 2013: 228). Many would agree that Shakespeare understood De copia and De conscribendis was the most popular textbook for the crucial skill of letterwriting. Where Cicero's mature treatise is also summarised in his most famous rhetorical text, De oratore, and again in De partitione (as discussed above), these texts were also the best-sellers for Cicero during the Elizabethan period (Mack 2013: 31), and we know Cicero was the undisputed Latin authority for rhetorical theory (Donker and Muldrow: 33). In De conscribendis, at the beginning of his discussion of inventio methods, Erasmus tells readers: 'I advise that you have recourse to the manuals of the rhetoricians, for if I were to try to treat each subject, I should run on too long' (1985: 110), which clearly indicates that if schoolboys were taught the full import of $D e$ conscribendis (which is likely), they were advised by Erasmus to incorporate training from the primary texts, which in this case would be Cicero's Topica. For these reasons, I am inclined to agree with Baldwin's assertion that Cicero's topical treatise was the most likely source for Shakespeare's foundational training on inventio - whether indirectly through Erasmus (with his masters' tutelage) or more directly through Cicero's Topica. This is in contrast to Trousdale and Mack's tendency to associate Shakespeare with Agricola's treatise, however whilst Shakespeare might have incorporated other topics into his repertoire throughout his career, it seems more likely that his original training on inventio was through Cicero - particularly where Agricola's treatise was considered the domain of the university (Mack 2010: 7), and Shakespeare is not known to have attended university.

\section{Desmonstrare artem and celare artem}

My analysis is guided by theories discussed by Heinrich Plett in Rhetoric and Renaissance Culture (2004). Plett discusses the prevalence of the courtly mode of celare artem during the Renaissance, where courtiers were expected to conceal the rhetorical artistry of their speech to make their eloquence seem natural. In response to this, Plett argues for an alternative culture of demonstrare artem at school, a term coined by Plett to account for the theory that school boys were taught to display their 
rhetorical art for assessment purposes before they were encouraged to conceal it (Plett: 78, 197-8, 471-2). As Lynn Enterline suggests, when discussing 'a day at school' in Renaissance England: 'What better way did a student have to fulfil the charge successfully to imitate classical exemplars before an audience of peers and masters than to point to his own verbal skill' (Enterline 2012: 37). Colin Burrow also notes: 'the grammar-school and university-educated men who made up the majority of those who wrote plays ... certainly wanted to display and use their classical learning' (Burrow 2013: 16, my emphasis). Such learning would have included classical theorists like Cicero as much as poets like Ovid.

As we shall see, an examination of Shakespeare's likely application of rhetorical precepts for inventio can be guided by these notions of concealing one's art (celare artem) or displaying aspects of its construction (demonstrare artem). A review of the topic headings of Cicero's treatise (listed above) will reveal that these are also terms that are used regularly in everyday discourse. Whilst to the rhetor, these present as a type of metalanguage for discussing aspects of normative discourse, the same terms also play an inconspicuous role within that normative discourse. This suggests that if Shakespeare was displaying an application of Cicero's topics (incidentally or more exhibitively), such display might be camouflaged before our eyes - hidden in plain view, as it were, to eyes that are unaccustomed to the metalinguistic nuances of these terms.

An example of a demonstrare artem display of a topic can be found in Baldwin's analysis of Shakespeare's use of the topic 'contraries', from The Tempest:

GONZALO:

148 I' th' commonwealth I would by contraries

149 Execute all things, for no kind of traffic

150 Would I admit; no name of magistrate [...] (Tempest, 2.1.148-150; Baldwin II: 115) (all Shakespeare references are to the Arden Complete Works).

This famous passage (which I have truncated) is built entirely on arguments from the contrary, and the first line displays the topic heading 'contraries' (148), so this becomes a credible claim that Shakespeare might have considered the topic of contraries during composition. An example of a celare artem use of topics is demonstrated by Baxter's assertion that a speech by Richard II uses the topic of division when discussing three kinds of uncontented thoughts:

11

12

18

23

The better sort,

As thoughts of things divine [...]

Thoughts tending to ambition $[\ldots]$

Thoughts tending to content [...] (RII, 5.5.11-23; Baxter: 139).

Nowhere are the words 'division' or 'partition' used in the speech, but the claim that an argument from 'the topic of division' has been used for purposes of clarity and detail becomes a credible celare artem claim to make. It becomes evident that, according to Plett's theory of demonstrare artem, such 'displayed' forms of evidence appear more convincing than do such celare artem claims, and these distinctions are useful for understanding previous approaches to Shakespeare's inventio, and certainly for understanding some of the problems involved in determining evidence for an art designed to be more ideational than textual. 


\section{Previous studies of Shakespeare's inventio}

Five scholars have attempted analyses of Shakespeare's application of topical invention, Baldwin (1942 II: 108-137), Baxter (1980: 136-143), Trousdale (1982: 5863), Mack (2010: 74-89) and Altman (2010: 120-133; 141-150). The first four present as single chapters within broader texts about Shakespeare's art, whilst Altman's analysis reaches across two chapters, indicating that a fuller account of the subject may be warranted. Joseph (1947/2005) structures her excellent work on rhetorical figures around Cicero's topical treatise (see her 'content' page where she also adds Agricola's topic of 'subject'), and whilst Joseph sometimes discusses a topic without reference to rhetorical figures, this remains a work about elocutio not inventio. Recent work by Skinner (2014) and Hutson (2015) sometimes discusses the circumstantial topics of Cicero's youthful De inventione, but Skinner is concerned predominantly with dispositio and neither articulates a topical treatise in any detail (Skinner avoids it entirely). When the abovementioned five contributors are collated, however, they create more confusion than any consensus on the subject.

For instance, Baldwin and Baxter observe Shakespeare's use of Cicero's treatise, whilst Trousdale and Mack observe the importance of Agricola's, and Altman focuses on Wilson's treatise (which is essentially Agricola's) whilst also discussing Agricola, Cicero and Ramus. Baxter and Trousdale examine only one soliloquy each, and Baxter often neglects to identify where he believes his topical attributions occur in the text (especially at 141), whilst Trousdale provides an informative account of Shakespeare's combination of Erasmian variation with topical invention, which tends to be a stronger account of Erasmian variation than it does of inventio methods. Neither Baxter, Trousdale, nor Mack include any references to the precepts from the treatise they are discussing, and because each scholar makes only celare artem claims (where no topical term appears in the passage) it sometimes becomes difficult to agree that an argument derives from similarities rather than comparisons, or from repugnants rather than contraries, from consequents rather than effects, without the correlative credence that recourse to the precepts would provide.

Although Mack never discusses Cicero's treatise, preferring Agricola's, the first topic he claims that Shakespeare uses is 'adjuncts' (2010: 75), which as we have seen, is a topic specific to Cicero's treatise. Agricola replaced 'adjuncts' with seven more specific topics, so if none of these are deemed relevant to the analysis, we must consider why the greater complexity of Agricola's treatise is thought to have been preferred by Shakespeare over Cicero's? Mack also suggests Shakespeare used the topic of consequences (2010: 84) - as Trousdale does in her Agricolan analysis (60) - yet we have seen that Agricola excluded 'consequences' from his treatise because he considered it to be a method of reasoning rather than a loci where arguments might be 'found' (Mack 1993, 148). Altman, who includes discussion of the relevant precepts, tends to delve deeper into the psychological aspects employed by Iago/Shakespeare, especially concerning circumstantial topics, but does not make a definitive claim for Shakespeare's preferred treatise.

Only Baldwin (1942) takes a systematic approach by seeking to find evidence for each of Cicero's topics used throughout Shakespeare's work, yet many of Baldwin's claims 
are questionable. Baldwin does refer to the relevant precepts, often by quoting large swathes of untranslated Latin with page references to old editions (rather than section references), and because Baldwin usually provides only one example for each topic, whenever his claims aren't convincing, they place chinks in the armour of his overall claim. Baldwin has viable claims for the topics of: [2] partition/division (II: 110,113); [7] similarities (quoting only two lines from Julius Caesar) (II: 115); [9] contraries (II: 115); and [10] adjuncts (II: 116). Interestingly, all these are desmonstrare artem claims where the topic heading is 'on display'. Baldwin's claims for the following topics, however, prove far more tenuous: [3] notatio: names/etymology (I: 719-20; II: 109, 115); [5] genus and [6] species (II: 111-115); [14] causes and [15] effects (II: 121); [16] comparisons - where no claim is made because Baldwin believes it to be self-evident (II: 122); and [11] consequents, [12] antecedents, and [13] repugnants (II: 116-120). Burrow reminds us of some 'weaknesses' to Baldwin's pioneering work that has taken time to be worked out in the secondary literature (Burrow 22).

From these past analyses, it becomes evident that making celare artem claims against Shakespeare's text is an exciting prospect towards which this field should be striving, but which may first need to be supported by foundational understandings of Shakespeare's topical methods that are best established by the demonstrare artem evidence that can be determined. For this reason, my analysis targets only demonstrare artem passages that seem to display the topical term, thus taking Cicero's topical headings as my search terms, including English variations for the terms when translated from the Latin. Shakespeare would almost certainly have learned inventio from the Latin, so Thomas Cooper's Latin/English thesaurus (1559) helps determine acceptable English variants for Cicero's terms - a translational method relied on by Baldwin, Skinner, and Burrow. Let us turn to an analysis of Shakespeare's use of the topic of notatio.

\section{Cicero's topic [3] notatio: name or etymology}

The third topic in Cicero's treatise is notatio: name or etymology, where the meaning of a word or the distinction between a thing and the words we attribute to that thing are considered. Cicero employs the topic in his explanation of it:

Many arguments are derived from notatio (etymology) ... when an argument is developed

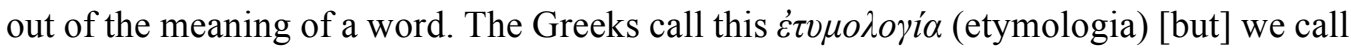
this kind notatio, because words are tokens (notae) of things (Topica, VIII.35-36: 409).

One aspect of this topic concerns names that exhibit particular etymologies, such as when Leonatus is construed from 'Leo-natus', or the lion's whelp (Cymb.: 5.5.444-6), as discussed by Baldwin (I: 719-20; II: 109, 115). This mode is however limited, and Joseph reminds us that this is: 'only one aspect of argument from the name [whilst] another is the relation between the name and the thing' (Joseph: 163, my emphasis). Elizabethan school boys would be familiar with this distinction because Erasmus's $D e$ duplici copia verborum ac rerum [De copia], one of the most popular writing manuals of the period, was structured around developing variations for words (verborum) and things (rerum). Today we might refer to the distinction between the signifier and the signified. 
This was a distinction Shakespeare seemed quite fond of, as when Juliet finds her way to the balcony and reduces her romantic plight to a mere matter of names:

33 O Romeo, Romeo, wherefore art thou Romeo?

34 Deny thy father and refuse thy name.

35 Or if thou wilt not, be but sworn my love

36 And I'll no longer be a Capulet (2.2.33-6, my emphasis).

These two arguments (33-34 and 35-36) consider forms of escape from the names inherited by birth, and each escape is from the patriarch who confers those names. Juliet continues:

38 'Tis but thy name that is my enemy:

39 Thou art thyself, though not a Montague.

$40 \quad$ What's Montague? It is nor hand nor foot

$41 \quad$ Nor arm nor face nor any other part

42 Belonging to a man (2.2.38-42, my emphasis).

Here, Shakespeare employs '[2] enumeration of parts' (40-42) to demonstrate by a method of exclusion the accidental quality of a name in relation to the object it signifies. Similarly, Shakespeare uses another 'enumeration of parts' in Falstaff's famous catechism about honour, although Shakespeare uses the word 'word' instead of 'name':

Can honour set to a leg? No. Or an arm? No. Or take away the grief of a wound? No. Honour hath no skill in surgery, then? No. What is honour? A word. What is in that word "honour"? ... Air. A trim reckoning! (1HIV, 5.1.131-135, my emphasis).

The topic of notatio is concerned chiefly with nouns, thus words which name a thing like 'honour', as Brutus says: 'I love/ The name of honour more than I fear death'. (JC, 1.2.88-9). When Cicero says that this topic concerns: 'when an argument is developed out of the meaning of a word', this process includes examining what the thing is that is denoted by the word. Juliet continues her contemplation using language that resembles Falstaff's:

$\begin{array}{ll}43 & \text { What's in a name? That which we call a rose } \\ 44 & \text { By any other word would smell as sweet; } \\ 45 & \text { So Romeo would, were he not Romeo call'd, } \\ 46 & \text { Retain that dear perfection which he owes } \\ 47 & \text { Without that title. Romeo, doff thy name, } \\ 48 & \text { And for that name, which is no part of thee, } \\ 49 & \text { Take all myself (2.2.43-9, my emphasis). }\end{array}$

Here, the word 'part' (48) [topic 6] seems to confirm that Juliet's earlier lines (40-42) had indeed been an 'enumeration of [Romeo's] parts'. This is a good example of the demonstrare artem evidence I am targeting, where secondary topics (parts/ partition) are seen to support the primary topic considered by the author (notatio: names). It seems Shakespeare's entire tragedy is driven by the inability of the hero and heroine to escape the roles determined by their accidental names, and Shakespeare has Juliet realize this.

Shakespeare continues to draw arguments from the inventions he seems to have brainstormed from this topic when he has Romeo say: 'Call me but love, and I'll be 
new baptis' 'd', and 'My name, dear saint, is hateful to myself.../ Had I it written, I would tear the word $(2.2 .50,55-7)$. Another of the many instances Shakespeare applies this topic, I suggest, occurs when Cassius grooms Brutus to join the conspirators $(\mathrm{JC}$, 1.2.141-149), and the speech by the King of France to Bertram is a particularly striking example that again negotiates the etymologies for 'honour/s' ( $A W, 2.3 .118-142)$. Shakespeare's fascination with this mode of reasoning seems to be far too erudite to be incidental, and his interest in names as a source for arguments certainly concurs with the precepts discussed by Cicero.

\section{Cicero's topic [9] Contraries}

In Cicero's discussion of the topic of contraries [contrariorum], he refers to four types of contraries regularly used in persuasive arguments:
i) opposites
(e.g., wisdom/folly)
ii) privatives
(e.g., 'in-'// 'un-', 'a-', 'non-', 'dis-', '-less')
iii) comparative
(e.g., long/short)
iv) negation
(e.g., 'If this is so, that is not') Topica, XI.47-49 (417-19).

The first type, opposites, relates to 'things which belong to the same class, but differ absolutely, as wisdom and folly', for 'when they are uttered, they are met face to face, as it were, by certain opposites [adversa]' (XI.47 [417]). The second type, privatives, concerns words combined with the prefix 'in-' to make them less forceful such as dignity (indignity), humanity (inhumanity) (XI.48 [417]). We may by extension include 'un-' (unyielding), 'a-' (asymmetric), 'non-' (non-negotiable), 'dis' (disinterested), and the suffix '-less' (harmless). The third type of contrary is comparatives, concerning those contraries 'which are compared with something, as double and single, many and few, long and short, greater and less' (XI.49 [417]), whilst the fourth type, negation, is described by Cicero as 'those intensely contrary expressions which are called negatives', and tend to take the form 'If this is so, that is not' (XI.49 [417-19]).

Where my analysis examines several of Shakespeare's passages that use cognates of 'contrary' or 'opposite' (English equivalents for Cicero's 'adversa'), the following example from Hamlet shows convincing evidence that Shakespeare understood and most probably applied Cicero's topic. The passage starts with Claudius admonishing Hamlet for grieving too long for his father (two months), employing the following arguments:

$\begin{array}{ll}92 & \quad \text { But to persevere } \\ 93 & \text { In obstinate condolement is a course } \\ 94 & \text { Of impious stubbornness. 'Tis unmanly grief; } \\ 95 & \text { It shows a will most incorrect to heaven, } \\ 96 & \text { A heart unfortified, a mind impatient, } \\ 97 & \text { An understanding simple and } \text { unschool'd; } \\ 100 & \text { [...] Why should we in our peevish opposition } \\ 101 & \text { Take it to heart? (1.2.92-97, 100-01). }\end{array}$

The word 'opposition' (100) alerts us to this passage, in which Shakespeare uses six privatives within four lines: three 'un-' words (unmanly, unfortified, and 
unschool'd); two 'im-' words (impious and impatient); and one 'in-' word (incorrect) (94-97), which conforms to Cicero's second class of contraries. The passage argues that the virtue of perseverance (92), indulged too long, can turn to the opposite vice of stubbornness (94), thus engaging Cicero's first class of opposites. The speech soon conforms to Cicero's fourth class, negation:

Fie! 'tis a fault to heaven,

102 A fault against the dead, a fault to nature,

103 To reason most absurd (1.2.101-03).

Following these three 'intensely' negative clauses that repeat the word 'fault' (101-2), Cicero's first class of contraries (opposites) is again used when Shakespeare sets 'reason' against 'absurdity' [logic against illogic] (103). Nine lines later, Claudius says that Hamlet's 'going back to school in Wittenberg' is 'most retrograde to our desire' (113-14), and although he no longer exhibits passive aggression towards Hamlet, the $O E D$ cites this use of 'retrograde' as its first recorded instance for meaning 'opposed, contrary, or contradictory' (5), helping to affirm that Shakespeare seemed determined to generate contrary arguments here for Claudius.

Why would Shakespeare focus so intensely on the topic of contraries for Claudius? It seems that whilst Claudius's arguments are logically astute (although pathologically insensitive), Shakespeare's use of contrariness was a rhetorical device employed to generate a dramatic effect - where Claudius is positioned subtly as Hamlet's antagonist at an early stage of the drama (1.2) coming before we understand that Claudius is suspected of killing Hamlet's father (1.5). Here, Shakespeare's apparent application of the topic of contraries contributes to the speech a coherent and uniform persuasiveness, even though we intuit Hamlet's grief to be a virtue, and seems also to suit the devilish compositional form of the 'anti-encomium', where one either praises a vice or, as in this case, dispraises a virtue.

\section{Cicero's topic ${ }^{1}$ Definition}

The six cognates of 'definition' used by Shakespeare includes five instances of 'define' and one coinage of the word 'definement'. It is from the latter example that I will argue Shakespeare negotiates the Ciceronian precepts for determining a formal definition. The term 'definement' occurs toward the end of Hamlet (5.2.98), after the pretentious courtier Osrick comes to invite Hamlet to a fencing match with Laertes. Osrick announces in prose:

OSRICK Sir, here is newly come to court Laertes ... an absolute gentleman, full of most excellent differences, of very soft society and great showing. Indeed ... he is the card or calendar of gentry, for you shall find in him the continent of what part a gentleman would see (5.2.91-97, my emphasis).

This causes Hamlet, who has 'stepped down' to prose to speak to Osrick (66), to identify Osrick's discourse as an attempted formal definition which Hamlet labels a 'definement': 
HAMLET Sir, his definement suffers no perdition in you, though I know to divide him inventorially would dazzle th'arithmetic of memory, and yet ... in the verity of extolment I take him to be a soul of great article and ... to make true diction of him, his semblable is his mirror, and who else would trace him, his umbrage, nothing more (5.2.98-105, my emphasis).

Shakespeare's ruse is simple: Osrick speaks in a conceited style and displays at least two topics of invention ([1] differences and [6] parts) in his attempt to formally define Laertes. He may also use 'continent' (containment) as a topic similar to wholes and parts. When Quintilian discusses topics of invention, he recommends making comparisons 'from part to whole' or 'from container to content' [ex eo quod continet ad id quod continetur] [1]. Osrick is merely working through these topics as buzzwords, however, because he fails to actually define any specific differences, parts or contents for Laertes (no military mind, no piercing eye, no chivalry, etc.). ${ }^{2}$ Picking up on this hollow formality, Hamlet identifies Osrick's rhetorical objective as a definement (some attempt at definition), before parodying this formal fault in his own response.

Indeed, Osrick's reference to 'differences' and Hamlet's reference to 'semblables' are key identifiers of a Ciceronian definition. Cicero encourages the use of up to nine other topics in the service of a definition and includes especially 'sameness and difference'. The traditional formula for a classical 'definition' begins usually with the genus (sameness) and its differentia. The traditional definition of a man, for instance, includes the genus 'animal', and the differentia 'rational', to create the formal definition of a man as a 'rational animal'. ${ }^{4}$ Hamlet's mindful reaching after a 'semblable' for Laertes is akin to someone considering the topic of 'similarities', and although Cicero recommends finding 'sameness and difference', Shakespeare's use of semblables is semantically closer to 'sameness' than it is to 'similarities', so becomes rather a correct method to use for a Ciceronian definition. This results in Hamlet's wry deduction that Laertes' 'mirror' - his reflection - or 'umbrage' (shadow or ghost), are the only things that could possibly 'trace' Laertes.

Cicero also recommends the topics of 'wholes' and 'parts' for helping definitions as well as the topic of 'division', explaining that 'definitions are made partly by enumeration [partitionum] and partly by analysis [divisionum]' (Topica V.28 [401]). This statement follows Cicero's distinction between 'defining things that exist', or material whole objects divisible by their parts, and 'things which are apprehended only by the mind', or conceptual notions, such as 'guardianship' that can only be divided by genus and species (V.26-7 [399]). In these passages, we find Osrick's reference to 'parts' is what prompts Hamlet to propose an 'inventorial' division of Laertes that 'would dazzle th'arithmetic of memory', and this sardonic compliment can also be found to be Ciceronian. Cicero tells us there is only 'a fixed number of species' divisible from any genus, whilst famously stating 'a division into parts [partium distributio] is more indefinite [infinitior], like drawing streams of water from a fountain' (VIII.33 [407]). This is because every part is made up of many other parts, so Hamlet's 'inventory' and use of 'arithmetic' suggest that his 'division' is an 'enumeration of parts' - those 'parts' of Laertes' mentioned by Osrick - and a division (or enumeration) of parts is the correct method because Laertes is a material object not a notional 
concept. According to Cicero, an enumeration or division of 'parts' could go on infinitely (infinitior), which would indeed dazzle th'arithmetic of memory.

If we examine the traditional interpretation of these passages we will find that a topical analysis provides a new and logical understanding of its problematic semantics. The Arden edition glosses Osrick's lines: 'the card or calendar of gentry' and 'the continent of what part a gentleman would see' as a cartographical conceit. This relies on 'card' being an archaic term for a map or mariner's compass (OED 3.a, 4.a), with 'calendar' glossed as a guide or directory (OED 3), and 'continent' as the largest landmass on such a map, whilst 'part' becomes the regions found on such a continent. The conceit amounts to Laertes becoming a metaphorical map of the largest continent of gentlemanly parts by which other men might orient their lowly positions. It is a wonderful conceit, yet it is shrouded in archaic semantics; it has no great relevance to the situation (outside of comic hyperbole), and its cartographic theme is never acknowledged by Hamlet.

A topical analysis, however, based on Hamlet's jesting around Osrick's failed definition, sees 'card' glossed as a file or piece of card such as those found in a library catalogue $^{5}$, with 'calendar' being the early form of index in a book, found at the front of devotional books such as The Book of Hours, with 'continent' referring to that which comprises or sums up or which is contained (OED, I.1.b.). This interpretation sees Osrick construing Laertes as a library catalogue or index page (a personified referencepoint) for a great volume (or volumes) on 'gentry', containing everything or 'what [ever] part' a gentleman 'would see' (or seek) for references to gentry. Such imagery of catalogues and indexes is appropriate to the topics of division, partition, enumeration, and definition, which are all alluded to by Hamlet. When Osrick says 'you shall find in him', I suggest this refers to a book or library catalogue rather than a map, and the listing quality of 'cards' and 'calendars' is what motivates Hamlet's use of 'inventory'. All this bookish imagery may also prompt Hamlet's use of 'article' and 'diction', where 'to make true diction of him' implies a verbal definition of Laertes, if not a diction-ary reference to him.

I suggest Shakespeare built this interchange around Osrick's failure to conceal his art according to the courtly mode of celare artem, and when he displays his art instead (the schoolboy mode of demomstrare artem), this prompts Hamlet to enjoy a jest by continuing Osrick's fault of defining nothing. These understandings of formal rhetoric are lost to us today but they would have been familiar to educated members of Shakespeare's audience, who would have enjoyed the comedy of errors. Where the modern actor might be forced to gesticulate this passage into the ether, a new rhetorical understanding of it could provide some better sense for the courtly semantics Shakespeare appears to display.

\section{Topical applications in 'Bennelong'}

I will now discuss brief examples of how I have re-applied these findings to my own play - The Tragicall Hiftorie of Woollarawarre Bennelong, Native Ambassador of Nova Hollandia. This is a blank verse drama that aims to harness something of Shakespeare's epic sweep and rhetorical force by imitating Shakespeare's creative 
processes. Bennelong explores the extraordinary relationship between Australia's first governor Arthur Phillip and the man, Bennelong, who was kidnapped to become Phillip's so-called 'ambassador'. Due to the great focus on Indigenous culture in this play, I have participated in consultation with (and continue to seek further consultation with) traditional owners and elders from the Aboriginal community in line with the protocols recommended by the Australia Council for the Arts. This has been a very productive and rewarding part of the play's development, particularly because I do not identify as an Indigenous person myself.

In turning to how Shakespeare's likely application of the topics of invention have been imitated in 'Bennelong', I will discuss several ways that I have considered the topic of names during composition and one instance where the topic of contraries has helped to shape a particular dramatic situation. In the prologue, which is spoken by a clever-lady called Stormfront, I have considered the topic notatio: etymology in the following:

$9 \quad$ Four-hundred nations all with splendour thrived

10 Th' day named Captain Cook us "terra nullius".

11 Terra: "the land"; nullus: "not any" -

12 The land 'twas never much belonged by many (Ben.: Prol.9-12).

The passage seeks to remind the audience of the great devastation caused by re-naming the landscape and people of an original culture, underlining the brutal irony of declaring a land inhabited by hundreds of thousands of people as belonging to no one. A prologue for a play like Bennelong would be bereft without allusions to this tragedy. In a scene between Patyegarang and Lieutenant Dawes, whom she visits regularly, Patyegarang snatches Dawes' notebook only to discover he has made changes to a painting of Sydney harbour:

PATYEGARANG [Astounded.]

Thy paintings on this page, ye sith hath scratched?

DAWES

Th' map of this great harbour, changed - revised;

Here Island one -

PATYEGARANG Boamillie.

DAWES

We named

After th' Shark; whose shape resembles much.

Here Island two -

PATYEGARANG

DAWES

Clark Isle; Lieutenant Clark plants pumpkins there.

Here Island five -

PATYEGARANG Memil, 'tis called.

DAWES We named

Goat Island - ruefully - for when six goats

Were landed there into thin air they vanishèd!

PATYEGARANG

This Memil Isle to Bennelong belongs;

Who feasted clans on sweet meats two moons gone (Ben.: 1.3.67-77). 
This passage continues to depict the violent effects that re-naming can have on original cultures - where the invasive usurpation of the European names: 'Shark', 'Clark', and 'Goat' and the feeble reasons they were chosen (etymology), becomes a violent act against a culture known now to be more than 40,000 years old.

In another example, Bennelong has been kidnapped by Arthur Phillip and kept in chains for three months, but has also been treated to lavish amounts of food and taught to speak English. This prompts a soliloquy from Bennelong who must escape back to his pregnant wife, Barangaroo, but he is also bemused by the affection he feels for his captor:
101 I hath "beanga" named him now - father.
102 And "doorow" kindly calls me he - his son.
103 Mine tribe hath mothered, uncled, auntied me
104 Till sure mine ears boxed blue; yet never hath
105 I fathered been since from mine youth mine flew.
106 Barangaroo grows pregnant with my child;
107 And I, to father-be, must farther be
108 From this father who kindly 'doorows' me (Ben.: 1.5.101-08).

The conference of the names 'father' and 'son' (which actually happened), operate more as titles than they do proper names, and becomes an exchange that is more binding than a contract, involving commitments to duty and affection between these unlikely candidates.

Shakespeare's apparent use of the topic of contraries in Hamlet has also assisted my approach to the opening scene of 'Bennelong'. The play opens with a depiction of the Europeans starving and enduring famine (the land will not work for them), and Phillip is running late for another public execution of convicts for stealing food, when the cantankerous Major Ross (antagonist to Phillip) unleashes invectives against the governor. My earlier drafts developed a number of fairly disconnected expletives, and this was because Ross must also convey the dramatic information of the famine. In recognising a similarity between this passage and that of Claudius, where Shakespeare needed to generate immediate conflict before the audience has had time to fully understand the character relationship, this lead to my application of the topic of contraries to help coordinate my composition (the Europeans speak in prose due to their fatigue):

ROSS Stand still, you bootless withering skelts! Fall out! Find shade! For palsy bedlams i' the mire could boast more lively flesh. O strictest Famine; daughter of Strife, damnèd sister of great Hardship! Disown thy claws' affection for our bones; uncrave thy sickly fondness for our brawn; unlock thy rancid kisses from our maws, distangle this too-prurient hunger for our dead!

COLLINS Od's heart, dear Major Ross, refrain!

ROSS Behold ourselves - each face looks drawn; eyes sunk; hair harsh; lips hoar; all kneepanes bulging huge! What nation e'er was nurtured on such groans? Here nothing grows, nothing proliferates, nothing finds its increase in this too ill-seasoned, too unripe, unpregnant and most uncultivable place so contrary to life! 
TENCH Desist thee, please!

ROSS Where hides thy magnus Phillip? 'Tis not enough he starves us daily, now doth starve us with delay his person too!

COLLINS [Aside.] Zounds; if I did pocket marbles as this man his injuries, I'd be as leaden to th' earth as is a tinker's ass laid-up with piles!

ROSS Trees without shade; flowers sans perfume; birds who cannot fly; beasts that do not have that common sense to bend them to all-fours! No wonder we of culture by this vasty place art spurned! (Ben., 1.1.1-19).

In his first outburst, Ross uses Cicero's second type of contrary (privatives): disown, uncrave, unlock, and distangle, whilst his second outburst uses the fourth type (negation) with a series of three intensely negative statements using 'nothing'. These are followed by another series of privatives: ill-seasoned, unripe, unpregnant and uncultivable, and the final outburst borrows from Marcus Clarke's preface to Adam Lindsay Gordon that expresses the 'Weird Melancholy' of a seemingly inverted Australian landscape, and contains elements of opposites as well as negatives to help vivify Ross's antagonism. This application of contraries, modelled on Shakespeare's precedent, does not rely on the persuasive effects of an 'anti-encomium', yet it does greatly strengthen the contrarious character of Ross's invectives, whilst contributing to the 'Shakespearean' aesthetic desired for the work.

\section{Conclusion}

It was T.S. Eliot who declared in 1921 that the tradition of writing blank verse drama like Shakespeare was 'dead', with its autopsy complete, because it had failed to be passed down to his generation (1921: 55-7). Eliot suggests that even Shelley's blank verse play, The Cenci (1819), was more a 'reconstruction' than participation in a tradition, which he refers to as 'all the difference between preservation and restoration' (56). Although Eliot would go on to write his own style of verse drama, it was not until the 1940's with Baldwin (1942) and Joseph (1947) that the first great discoveries about Shakespeare's intricate application of rhetorical precepts began to emerge. Many scholars have since alerted us to the visible devices of rhetorical figures in Shakespeare's work, though the brief analyses of Shakespeare's inventio have so far been exploratory, whetting our appetites, without becoming a definitive source for the subject. It is towards the promotion of a stronger foundation in this field that this paper aims to supply some precedent. Working from the creative perspective of wanting to re-apply the practical components of my findings about Shakespeare's creative process allows me to view his methods of inventio from a different perspective to the historian of rhetoric. The ability to ask: will this allow me to achieve a similar effect in my own work? helps drive a more purposeful approach to understanding Shakespeare's use of inventio, methods that at first seem enigmatic, but which have always been inherently practical. My own modest illustrations of how these findings can be re-applied in new work that aims to achieve a 'Shakespearean' aesthetic demonstrates an ability to reengage with systems of composition that were known to the Elizabethans, but which were not known to Shelley or Eliot. Whilst a tradition relies on a greater number of 
people than one person engaging in the same practice, the prospect of 'restoring' an artisanal dramatic tradition that was once declared dead becomes an exciting prospect for scholars engaged in creative practice as well as Shakespeare studies.

\section{Endnotes}

1. Quintilian, 5.10 .90 (413). See also 'continent' as 'that which contains or holds' (OED, I.1.a.) and Hamlet (2013), glossing 'continent' as possibly meaning 'container', 440-441.

2. Osrick's mention of 'soft society' and 'great showing' appear to be generalizations attributable to any gentleman rather than specific things that define or set Laertes apart.

3. See: (2) division/enumeration of parts, (5) wholes, (6) parts, discussed in Topica, V.26-27 (399, 401); and (5) genus, (8) differentia, (9) contraries, (8) differences, (7) similarities, (11) consequences, and (3) name/etymology, discussed in Partitiones, XII.41 (343), whilst 'sameness and difference' is especially recommended in Topica, XXIII.87-88 (451).

4. See for example Quintilian's discussion of 'Genus, Species, Difference, and Property' as the topics he particularly recommends for a formal definition, 5.10 .56 (393-5).

5. For $O E D$ 's 'card-catalogue', listed under 'card', we get 'a catalogue (of a library, etc.) in which each item is entered on a separate card' $(O E D 2)$.

\section{Works cited}

Baldwin, TW 1944 William Shakspere's Small Latine \& Lesse Greeke [2 vols] Urbana: U of Illinois Press

Baxter, John 1980 Shakespeare's Poetic Styles: Verse into Drama London: Routledge \& Kegan Paul

Burrow, Colin 2013 Shakespeare \& Classical Antiquity Oxford: Oxford UP

Cicero 1942a Divisions of Oratory [De partitione oratoria] Trans H Rackham. Loeb Classical Library [349] Cambridge, MA: Harvard UP

Cicero 1942b On the Orator [De oratore] Books 1-2 [348] trans EW Sutton and H Rackham, Book 3 [349] trans H Rackham, Loeb Classical Library Cambridge, MA: Harvard UP

Cicero 1949a On Invention [De inventione] Trans HM Hubbell, Loeb Classical Library [386]

Cambridge, MA: Harvard UP

Cicero 1949b Topics [Topica] Translated by H M Hubbell Loeb Classical Library [386] Cambridge, MA: Harvard UP

Donker, Marjorie and Muldrow, George M 1982 Dictionary of Literary-Rhetorical Conventions of the English Renaissance Connecticut: Greenwood

Eliot, TS 1921 'The Possibility of a Poetic Drama', in The Scared Wood: Essays on Poetry and Criticism New York: Alfred A Knopf

Enterline, Lynn 2012 Shakespeare's Schoolroom: Rhetoric, Discipline, Emotion Philadelphia: U of Pennsylvania Press

Erasmus, Desiderius 1978 "De duplici copia verborum ac rerum commentarii duo" ["De copia"] trans and annotated Betty I Knott, in Collected Works of Erasmus [Vol 24], ed Craig R Thompson, Toronto: U of Toronto Press

Erasmus, Desiderius 1985 'De Conscribendis Epistolis' In Collected Works of Erasmus (Vol 25) [*notes in Vol 26], ed J K Sowards, Toronto: U of Toronto Press

Hunter, George K 1994 'Rhetoric and Renaissance Drama’ In Renaissance Rhetoric, ed Peter Mack Hampshire: Macmillan 
Hutson, Lorna 2015 Circumstantial Shakespeare Oxford: Oxford UP

Joseph, Sister Miriam 1947/2005 Shakespeare's Use of the Arts of Language Philadelphia: Pauls Dry

Mack, Peter 1993 Renaissance Argument: Valla and Agricola in the Traditions of Rhetoric and Dialectic Leiden: EJ Brill

Mack, Peter 2010 Reading and Rhetoric in Montaigne and Shakespeare London: Bloomsbury Academic

Mack, Peter 2013 A History of Renaissance Rhetoric: 1380-1620 Oxford: Oxford UP

Plett, Heinrich F 2004 Rhetoric and Renaissance Culture Berlin: Walter de Gruyter

Quintilian 2001 The Orator's Education [Institutio Oratoria] Ed and trans Donald A Russell, Loeb Classical Library [124, 125, 126, 127, 128] Cambridge, MA: Harvard UP

Shakespeare, William 2013 Hamlet [Arden Third Series], ed Ann Thompson and Neil Taylor, London: Bloomsbury

Shakespeare, William 2014 The Arden Shakespeare Complete Works, ed Richard Proudfoot, Ann Thompson and David Scott Kastan, Sydney: Bloomsbury

Skinner, Quintin 2014 Forensic Shakespeare Oxford: Oxford UP

Trousdale, Marion 1982 Shakespeare and the Rhetoricians Chapel Hill: U of North Carolina Press 